\title{
Trends in the evolution of floodplain management in Australia: Risk assessment, precautionary and robust decision-making.
}

\section{Trends in the evolution of floodplain management in Australia: Risk assessment, precautionary and robust decision-making.}

\author{
Key words: Floodplain development, flooding, litigation, judicial reasoning, risk \\ assessment, precautionary principle
}

\begin{abstract}
This article tracks the evolution of floodplain development policy in Australia and analyses some recent case law in the light of that policy. Although the dominant policy paradigm promotes strategic risk management combined with affordable and proportionate risk mitigation, the case law analysed adopts a more risk averse and normative tone. There seems to be a clear dichotomy between the risk management approach of the main policy documents and actual practice, at least in the courts. The reasons for this divergence and some reflections on the future of the precautionary principle in the light of this evidence are discussed in the final sections.
\end{abstract}

\section{Introduction}

Over the past thirty years the policy approach to managing natural disasters has evolved considerably. Thirty years ago the main objective was to ensure the safety and protection of people and property during and immediately after natural disasters. ${ }^{1}$ Managing the 'disaster cycle' involved preparation, emergency response, rehabilitation and reconstruction in the immediate aftermath of a disaster. ${ }^{2}$ Since the 1990s, however, the rising costs of disaster relief have prompted a more fundamental analysis of disasters leading to a more holistic approach. This evolution is evident in both international ${ }^{3}$ and national fora. ${ }^{4}$

\footnotetext{
${ }^{1}$ A Lavell, M Oppenheimer, C Diop, J Hess, R Lempert, J Li, R Muir-Wood and S Myeong "Climate change: new dimensions in disaster risk, exposure, vulnerability and resilience" C Field et al, Managing the Risks of Extreme Events and Disasters to Advance Climate Change Adaptation, A Special Report of Working groups I and II of the Intergovernmental Panel on Climate Change (IPCC) (CUP: 2012) 37 (SREX Report).

2 SREX Report (n 1) 35.

${ }^{3}$ World Conference on Disaster Risk Reduction (WCDRR), Hyogo Framework for Action, 2005-2015; WCDRR, Sendai Framework for Disaster Risk Reduction 2015-2030 (United Nations, 2015). See further, the home site of the United Nations Office for Disaster Risk Reduction (UNISDR) at: https://www.unisdr.org/ (viewed 22/02/2018).

${ }^{4}$ For Australia, see, National Strategy for Disaster Resilience, 2011. For Europe, see: EU Commission, Flood risk management - Flood prevention, protection and mitigation (EU Commission Communication, 12/07/2014); EU Directive 2007/60/EC on the assessment and management of flood risks. For the United Kingdom, see, Defra, National Flood and Coastal Erosion Strategy (UK) (Defra and Environment Agency,
} 
Today's disaster managers recognise the importance of long term planning for disaster risk reduction in addition to more traditional notions of disaster management. Disaster risk reduction seeks to reduce the risks associated with disasters well before they occur. It is:

[B]oth a policy goal or objective, and the strategic and instrumental measures employed for anticipating future disaster risk, ${ }^{5}$ reducing exposure, hazard or vulnerability, and improving resilience. ${ }^{6}$

Key goals of disaster risk reduction include reducing vulnerability - the propensity or predisposition to be adversely affected" - and exposure - the location of "people, livelihoods, environmental services and resources, infrastructure, or economic, social, or cultural assets in places that could be adversely affected by physical events." ${ }^{8}$ The emphasis on reducing vulnerability and exposure means disaster risk reduction is inherently concerned with land use planning and development law. These prior existing regulatory frameworks provide the engine room for realising disaster risk reduction.

This article offers a case study of disaster risk reduction strategies in relation to Australian floodplains. It seeks to identify operational perspectives on flood management - that is, how national and state policy is stated, interpreted and applied in the context of actual decisions about particular development applications on flood prone land. To that end, it explores some relevant case law emanating from the planning and environment courts and tribunals in New South Wales, Victoria and Queensland. In Australia, these courts and tribunals undertake merits review of a range of planning and development disputes. They are actively engaged in shaping how the law develops. Although these courts and tribunals decide only a small minority of development applications, their judgments offer well-reasoned, transparent decisions - allowing us to identify decision-makers' styles of reasoning and to see how the interpretation of policy instruments translates into decision-making 'on the ground'. They offer an interesting, transparent and informative perspective on decisionmaking in situations of risk and uncertainty. In show casing some of their jurisprudence, this

2011); M. Nye, S. Tapsell and C. Twigger-Ross, "New social directions in UK flood risk management: moving towards flood risk citizenship?" Journal of Flood Risk Management 4 (2011) 288-297; Jaap Filkweert, Paul Hart and Charlotte Spliethoff, "Space for water: Sharing lessons on floodplain management policy between Queensland, the Netherlands and England" 2013 available at:

http://www.floodplainconference.com/papers2013/Charlotte\%20Spliethoff\%20Full\%20Paper.pdf (viewed 06/03/2108).

${ }^{5}$ In the SREX Report disaster risk is defined as, "The likelihood over a specified time period of severe alterations in the normal functioning of a community or a society due to hazardous physical events interacting with vulnerable social conditions, leading to widespread adverse human, material, economic, or environmental effects that require immediate emergency response to satisfy critical human needs and that may require support for recovery." SREX Report (n 1) 32.

${ }^{6}$ SREX Report (n 1) 34. In the SREX Report resilience is defined as "The ability of a system and its component parts to anticipate, absorb, accommodate, or recover from the effects of a potentially hazardous event in a timely and efficient manner, including essential basic structures and functions." SREX Report (n 1) 34.

${ }^{7}$ SREX Report (n 1) 32.

${ }^{8}$ SREX Report (n 1) 32. 
article attempts to describe and illuminate the actual practice of risk management in land use planning and development.

The scheme of this article is first to describe the evolution of floodplain management in Australia. This section draws on the 2000 SCARM Report, Floodplain management in Australia: best practice principles and guidelines (SCARM Report) ${ }^{9}$ and its successor, Managing the floodplain: a guide to best practice in flood risk management in Australia (AEM Handbook). ${ }^{10}$ In the absence of comprehensive national legislation on the matter, ${ }^{11}$ the AEM Handbook represents current best practice in floodplain management in Australia.

Consistent with trends across the developed world, ${ }^{12}$ the analysis identifies a mainstream policy favouring the use of comprehensive risk assessment techniques feeding into strategic, land use planning tools to manage land use and development on floodplains. An historic reliance on hard engineering solutions to defend against flooding risks has given way to a more nuanced approach in which flooding risks should be holistically assessed and managed following an analytic-deliberative model of policy development.

However, this analysis also identifies two supplementary, more discrete, policy trends. First, in the latest policy advice, there is some qualified support for a more risk averse approach to decision-making in hard cases. Secondly, a number of desirable outcomes are suggested to help steer decision-making. As will be seen, these supplementary decision-making strategies have proven particularly useful to the courts - where, of course, hard cases tend to be the norm.

In the second section, this article briefly describes key planning documents and instruments relied on in three Australian states - New South Wales, Queensland and Victoria - to provide the regulatory context for the case law subsequently discussed. There are some identifiable disparities across these instruments which may be ironed out over time. As with the national policy documents, the newer instruments include desired outcomes - or policy principles to assist decision-makers.

After reviewing the relevant planning instruments, the discussion in this article turns to the treatment of flooding risk in three court judgments across different Australian jurisdictions - Queensland, New South Wales and Victoria. Whilst by no means a quantifiably representative sample, these cases exemplify the debates, issues and gaps in our knowledge about managing flooding risk during urban development. They illustrate the "framing power" of legal institutions in relation to the assessment of technological risk. ${ }^{13}$ By and large the

\footnotetext{
${ }_{9}^{9}$ Agriculture and Resource Management Council of Australia and New Zealand, Floodplain management in Australia: best practice principles and guidelines (SCARM Report no 73) (CSIRO Publishing, 2000) (SCARM Report).

${ }^{10}$ Commonwealth of Australia, Managing the floodplain: a guide to best practice in flood risk management in Australia, (AEM Handbook no.7) (Commonwealth of Australia, 2013) (AEM Handbook).

${ }^{11}$ Australia has a federal governance structure in which the states have primary responsibility for natural resources and urban planning.

12 See $n 4$.

${ }^{13}$ Elizabeth Fisher, Risk Regulation and Administrative Constitutionalism (Hart Publishing, 2007) 253.
} 
judiciary is not noted for its pro-environment, anti-development ethos. ${ }^{14}$ Nevertheless, and perhaps surprisingly, each case illustrates a quite conservative - or risk averse - approach to new development on flood prone land. This finding throws into sharp relief the distinction between mainstream, official policy - favouring strategic, risk based, land use planning combined with adaptive management - and the evidence that a more conservative, risk averse approach is being favoured in the courts and, at least in these cases, within local councils too.

Two trends in floodplain decision-making emerge from this analysis of floodplain policy and the case law. First, there are some emerging criteria - or policy principles - which sow the seeds of a generic, normative framework for planning and development decisions dealing with flooding risks. The AEM Handbook identifies some specific objectives which, with or without reference to that Handbook, have routinely been considered by the courts when considering individual cases. This principled and normative approach to decision-making has found more favour than recourse to cost-benefit analyses or other more sophisticated methods of risk assessment. Secondly, the decision-making journey in each case led to a risk averse result. Surprisingly, that was the result in both council decision-making and in the courts. Whereas official policy documents favour sophisticated risk assessment techniques combined with a mitigate-and-adapt approach to managing flooding risks, actual practice 'on the ground' is more conservative.

In the final section, this article considers the persistence of risk aversion in relation to the evolution of the precautionary principle in Australia and elsewhere. It argues that, in recent times, the precautionary principle has become shackled by notions of proportionality, cost effectiveness and adaptive management. Whilst these refinements answer to critiques of the precautionary principle - that it is unscientific, excessively risk averse and economically inefficient - they also play into the hands of a 'business as usual' trajectory. The persistence of risk averse decision-making in flooding cases suggests that, whatever refinements these technical stipulations bring to the application of the precautionary principle, there is still a role for a more conservative (or sceptical) approach to decision-making about risks. Drawing on contributions from the climate change adaptation literature, this article suggests that risk averse decision-making is a form of robust decision-making. The literature surrounding robust decision-making provides an alternative rationale to the precautionary principle and broadens the debate about what constitutes 'good' decision-making in hard cases.

\section{The Evolution of Floodplain management in Australia - from one technical fix to another?}

The risk of flooding across large areas of agricultural and urban land has long been recognised in Australia. In 1817, Lachlan Macquarie, then Governor of New South Wales, wrote to each of the churches and chapels throughout the Colony expressing his "[M]ost sincere Concern and regret for the recent Calamities, in which the unfortunate Settlers on

\footnotetext{
${ }^{14}$ For a sample of unsuccessful community based litigation raising environmental issues, see: Greenpeace Australia Ltd v Redbank Power Co Pty Ltd (1994) 86 LGERA 143; Friends of Hinchinbrook Society Inc v Minister for the Environment (1997) 142 ALR 632; Minister for Planning v Walker [2008] NSWCA 224; Xstrata Coal Queensland Pty Ltd v Friends of the Earth - Brisbane Co-Op Ltd [2012] QLC 13; Australian Conservation Foundation Incorporated v Minister for the Environment [2016] FCA 1042.
} 
the Banks of the Nepean and Hawkesbury have been once more involved by the late dreadful inundations of those Rivers". On a harsher note, he warned existing settlers to remove their residences to the "Townships assigned for them on the High Lands" or be left with no assistance from the Government in future floods. ${ }^{15}$

Despite Lord Macquarie's advice, development on Australian floodplains has continued apace. Until the 1970s, Australian governments relied primarily on engineering solutions, particularly levees, to deal with flood risks. A number of severe floods in the 1970 s exposed the high cost and limited effectiveness of this strategy. ${ }^{16}$ From the early 1970s, Australian states started to insist that all new development should be built to a standard that would offer protection against inundation if or when a defined flood event (DFE) - defined by reference to the Annual exceedance probability (the AEP) - should occur. ${ }^{17}$ Keeping floor levels above the 1\% AEP became the standard requirement for new development in flood prone areas. Unfortunately, this additional measure did not fully solve the problem: flood prone communities remained exposed and governments at every level faced a growing bill for dealing with flood damage. ${ }^{18}$ By the early 1990s, the need for a more comprehensive strategy, capable of both a more nuanced and a more holistic approach, was widely recognised both within Australia and abroad. ${ }^{19}$

The new approach to flooding was encapsulated in the 2000 publication, Floodplain Management in Australia: Best Practice Principles and Guidelines (SCARM Report). ${ }^{20}$ The SCARM Report acknowledged the "immense value" of Australian floodplains as the "commercial, social and ecological arteries of the nation" 21 and it sought to encourage the planning and use of floodplains as "a valuable and sustainable resource capable of multiple

\footnotetext{
${ }^{15}$ SCARM Report (n 9) 46.

${ }^{16}$ SCARM Report (n 9) 9.

${ }^{17}$ The Annual exceedance probability (AEP) is the likelihood of the occurrence of a flood of a given or larger size occurring in any one year, usually expressed as a percentage. For example, if a peak flood flow of 500 $\mathrm{m} 3 / \mathrm{s}$ has an AEP of $5 \%$, it means that there is a $5 \%$ chance (that is, a one-in-20 chance) of a flow of $500 \mathrm{~m} 3 / \mathrm{s}$ or larger occurring in any one year. The AEP may also be referred to as the average recurrence interval (ARI). See, SCARM Report (n 9) 96.

${ }^{18}$ SCARM Report (n 9) 9; AEM Handbook (n 10) 12; Australian Business Round table for disaster resilience, Building our Nation's Resilience to Natural Disasters (Deloitte Access Economics, June 2013) <http://australianbusinessroundtable.com.au/our-papers/white-paper > accessed 20 November 2017; Australian Business Round table for disaster resilience, The economic cost of the social impact of natural disasters, (Deloitte Access Economics, 2016)

$<$ http://australianbusinessroundtable.com.au/assets/documents/Report\%20\%20Social\%20costs/Report\%20-

\%20The\%20economic\%20cost\%20of\%20the\%20social\%20impact\%20of\%20natural\%20disasters.pdf> accessed 20 November 2017.

${ }^{19}$ Selina Begum, Marcel Stive and Jim Hall (eds), Flood risk management in Europe: Innovation in policy and practice (Springer, 2007); Thomas Hartmann, Clumsy Floodplains: Responsive Land Policy for Extreme Floods (Ashgate, 2011); Thomas Hartmann and Juliane Albrecht, "From flood protection to flood risk management: condition-based and performance based regulations in German water law" (2014) 26 JEL 243. See also $n 4$.

20 SCARM Report (n 9). See also, AEM Handbook (n 10).

${ }^{21}$ SCARM Report (n 9) 1.
} 
but compatible, land uses"..$^{22}$ It argued a comprehensive, forward looking, land use planning instrument was the most appropriate method for achieving this goal and it described procedures for preparing individual floodplain management plans for each floodplain. ${ }^{23}$ Acknowledging huge diversity across individual floodplains, it rejected a one size fits all approach. It accepted, for instance, different return periods (or ARIs) may be adopted in different areas and for different types of development at the discretion of individual floodplain entities. ${ }^{24}$ In summary, the SCARM Report favoured a strategic, evidence based and adaptive approach to land use planning and development control.

To ensure effective implementation, the SCARM Report envisaged that, once finalised, each floodplain management plan would be incorporated into local councils' statutory land use planning instruments. ${ }^{25}$ It argued that, more than any other management measure, "Land use planning controls are the most cost effective means of reducing the growth in future flood damage". 26

If the foremost message of the SCARM Report was the need for strategic and adaptive risk management there were at least two ways in which the SCARM Report offered scope for a subtle, pro-development agenda to operate in conjunction with strategic risk management. First, it accepted development would and should continue to occur on flood prone land and, furthermore, it will generally be "economically and practically infeasible to provide complete flood protection up to the PMF (probable maximum flood) event". ${ }^{27}$ That being the case, the primary objective should be "to reduce the effect of flooding and flood liability on individual owners and occupiers of flood-prone property, and to reduce private and public losses resulting from floods" to "acceptable levels". ${ }^{28}$ Clearly the SCARM Report envisaged (and even condoned) continuing development on flood prone land so the real question for decision-makers was, "what is acceptable development"? On this question, the SCARM Report was rather more opaque. It did accept, however, that outside any extreme hazard zone, ${ }^{29}$ commercial, industrial and, in some cases, even residential development, may be

\footnotetext{
22 SCARM Report (n 9) 4.

23 SCARM Report (n 9) 3.

${ }^{24}$ SCARM Report (n 9) 76. See also $n$ (17).

${ }^{25}$ SCARM Report (n 9) 6.

${ }^{26}$ SCARM Report (n 9) 70. Other management measures are: structural controls, development and building controls and flood emergency measures. The flood management options identified in the SCARM Report are: avoid the risk (e.g. through land-use planning); reduce the likelihood of floods occurring (e.g. by structural measures to provide protection); reduce the consequences of flooding (e.g. through building regulations); transfer the risk of flooding (e.g. through insurance) (this was not a current option in Australia); finance the risk (e.g. through the Commonwealth's Natural Disaster Relief Arrangements); and accept the risk (e.g. by preparing for residual risk in flood emergency measures, SCARM Report (n 9) 7- 9.

27 SCARM Report (n 9) 1.

${ }^{28}$ SCARM Report (n 9) xiv and 4.

${ }^{29}$ Without pre-determining the relevant ARI and DFE in any particular case, the SCARM Report envisaged the categorisation of all flood-prone land on a scale ranging from low hazard to extreme hazard. In an extreme hazard zone, the only appropriate land uses would be rural, recreational, open space and environmental uses. See SCARM Report (n 9) xvi.
} 
appropriate if "special controls" are put in place. ${ }^{30}$ These "special controls" should aim to reduce the risk to "As Low as Reasonably Practical" (ALARP principles) with due regard to the affordability of risk management measures. ${ }^{31}$ Thus, the SCARM Report accepted that, what constitutes an acceptable level of risk would for the most part be defined by the availability of "affordable" risk management measures, a formula seemingly tailor made for profit driven, development proponents. ${ }^{32}$

The second aspect of the SCARM Report which could play into the hands of a prodevelopment agenda related to the preparation of floodplain management plans. As we have seen, the SCARM Report's model framework for preparing a floodplain management plan was fundamentally premised on notions of comprehensive, localised risk management. Risk management, however, is not and never will be an "exact science". ${ }^{33}$ Whereas practitioners of risk identification may, with partial validity, ${ }^{34}$ claim to be assembling purely objective, scientific evidence, risk management requires decision-makers, sooner or later, to convert factual, relatively objective information into normative principles and operational decision rules. ${ }^{35}$ This is a process that inevitably requires the exercise of judgment and discretion making the practice of risk management a much more fuzzy process than risk identification. ${ }^{36}$

To assist decision-makers in the all-important task of setting the parameters for risk management, the SCARM Report suggested combining economic appraisal - which would provide a common framework for assessing the effects of alternative management options - and active public consultation to elicit "the community's wants and desires regarding the development and use of flood prone land". ${ }^{37}$ A deliberative process, informed by all the "facts" resulting from the comprehensive, multi-disciplinary analysis would then lead to a well-informed, reliable and generally non-contentious floodplain management plan in which

\footnotetext{
${ }^{30}$ SCARM Report (n 9) xvi.

${ }^{31}$ SCARM Report (n 9) 52. Although elsewhere in the Report it accepts that acceptable levels of risk must have regard to "affordable" risk management, SCARM report (n 9) 4.

32 SCARM Report, (n 9) 4.

${ }^{33}$ Carlo Jaeger and others, Risk, Uncertainty and Rational Action (Earthscan, 1999) Ch 5; Fisher (n 13); Adams, J, "A Richter scale for risk?" in Julian Morris (ed), Rethinking Risk and the Precautionary Principle (Butterworth Heinemann, 2000) 229-245; Paul Slovic, The Perception of Risk (Earthscan, 2000); Andreas Klinke and Ortwin Renn, "A new approach to risk evaluation and management: risk-based, precaution-based and discourse-based strategies" (2002) 22(6) Risk Analysis 1071, 1075.

${ }^{34}$ On forms of scientific uncertainty affecting risk identification, see Fisher (n 13) 8; Robert Matthews, "Fact versus factions: the use and abuse of subjectivity in scientific research" in Morris (n 33) 247- 282.

${ }^{35}$ Fisher (n 13) 7; Jaeger (n 33) 112-119.

${ }^{36}$ Baruch Fischhoff and others, Acceptable Risk (CUP, 1983) 2; Fisher (n 13) 14, 17; Royal Society (Great Britain) Study group on risk, Risk, Analysis, Perception and Management, (Royal Society 1992); Klinke and Renn (n 33) 1075. See also, European Commission, Communication on Precaution (EC COM (2000) 2-2-00 s 5.2.1 in which it is stated (with reference to use of the precautionary principle), "the appropriate response in a given situation is thus the result of an eminently political decision, a function of the risk level that is 'acceptable' to the society on which the risk is imposed".

${ }^{37}$ SCARM Report (n 9) 16.
} 
management objectives, strategies and measures are broadly aligned with the "community's wants and desires". ${ }^{38}$ These recommendations promote a combination, 'analyticdeliberative' process which readily aligns with the 2009 standards for risk management adopted by the International Organization for Standardization (ISO) and overseas authorities. ${ }^{39}$

Despite the well-meaning aspirations of the 'analytic-deliberative' process, it does little to resolve the underlying and long standing tension between scientific and social analyses of risk. ${ }^{40}$ It is well recognised, for example, that cost-benefit analyses, favoured in the SCARM Report, are inherently flawed when social and environmental issues are at stake because there is still no common basis for comparing quantifiable (cost) and non-quantifiable (social and environmental) issues. ${ }^{41}$ Compounding the problems, long term future impacts are usually heavily discounted in these sorts of equations, meaning the short term economic benefits of development will almost always seem to outweigh any long term, adverse social and environmental risks. ${ }^{42}$ Needless to say, developers propose new development precisely because it is perceived as profitable to do so! The community, on the other hand, may display quite divergent views about its preferred level of exposure to flooding risk. Individuals and communities form different appetites for risk based on their own views and experiences; ${ }^{43}$ their views may fluctuate widely over time and they may seem illogical and irrational when compared against the costs of risk aversion and the economic benefits of development. ${ }^{44}$ Juggling all these considerations, decision-makers may easily be drawn towards favouring the certainty of short term, economic benefits over and above their community's views on the weight to be given to adverse social and environmental risks. ${ }^{45}$ After all, a short term, cost-benefit analysis offers "a simple model of control and accountability, and accountability is the obsession of the contemporary age". ${ }^{46}$

\footnotetext{
${ }^{38}$ SCARM Report (n 9) 16.

${ }^{39}$ International Standardization Organization, Risk Management - Principles and Guidelines, 2010 (AS/NZS ISO 31000:2009). In the United States, the origins of the analytic-deliberative process can be sourced to the National Research Council's influential report edited by Paul Stern and Harvey Fineberg (eds), Understanding Risk: Informing Decisions in a Democratic Society (National Academy Press, 1999). See further, Elizabeth Fisher, "Risk and environmental law: A beginner's guide" in Ben Richardson and Stepan Wood (eds) Environmental Law for Sustainability (Hart Publishing, 2006) 97.

${ }^{40}$ Klinke and Renn (n 33) 1075; Fisher (n 13) chapter 1; Royal Society (n 36).

41 Jaeger (n 33) 109-112; Fisher (n 13) 14, 17.

42 Fisher (n 13) 19; Klinke and Renn (n 33) 1081.

${ }^{43}$ Ortwin Renn, "Concepts of risk: a classification" in Sheldon Krimsky and Dominic Golding (eds), Social Theories of Risk (Praeger 1992) 64-76.

${ }^{44}$ Slovic (n 33); Jaeger (n 33) chapter 5; Klinke and Renn (n 33) 1075; John Adams, "A Richter scale for risk?" in Morris (n 33) 229; Marcela Brugnach and others, "Toward a relational concept of uncertainty: About knowing too little, knowing too differently, and accepting not to know" (2008) 13(2) Ecology and Society 30, 31; Torsten Grothman and Fritz Reusswig, "People at risk of flooding: why some residents take precautionary action and others do not" (2006) 38 Natural Hazards 101.

${ }^{45}$ Fisher (n 13) 250-251.

${ }^{46}$ Fisher (n 13) 21.
} 
In 2013 the Australian Emergency (AEM) Handbook no. 7 replaced the SCARM Report. The AEM Handbook continues the emphasis on strategic, risk based, land use planning for floodplain management but that emphasis is now qualified by some clear environmental parameters on decision-making. These serve to temper the pro development stance of its predecessor. For instance, in the AEM Handbook, the overall vision is to ensure "Floodplains are strategically managed for the sustainable long-term benefit of the community and the environment, and to improve community resilience to floods". ${ }^{47}$ This vision is carried through into the chapters of the AEM Handbook on planning for future development. Decision-makers are instructed to ensure the natural functions of the flood plain are maintained as this is "essential to effective management". ${ }^{48}$ Although these objectives were also raised in the SCARM Report, they seem to have acquired an elevated status in the AEM Handbook.

Although the AEM Handbook continues to promote the use of floodplain management plans as the most effective means to address future flood risk, it does acknowledge the limitations of this approach. It notes floodplain management entities (FMEs) are "at different points on a path towards best practice." 49 Where the relevant studies are incomplete or there are gaps in the knowledge base, decision-makers are encouraged to exercise their powers, "in a precautionary way using the best available information in a conservative manner." 50 This information is 'tucked away' in the main text without further explanation and there is no cross reference to the legal version of the precautionary principle as recognised in Australian law (discussed below) and other jurisdictions. ${ }^{51}$ Therefore, to avoid confusion with its legal counterpart, we shall refer to this statement as simply a 'conservative' approach. Arguably, this conservative approach is at odds with the cost-benefit language of its predecessor, the SCARM Report.

In another advance on the SCARM Report, the AEM Handbook identifies some specific outcomes that development purporting to offer an acceptable level of risk should meet. To ensure that risk is reduced to acceptable levels, future development should:

- have limited impact on the flood risk of the existing community including its emergency response capability;

- be compatible with flood functions and hazard;

- ensure people who are more vulnerable will be located in less-exposed areas;

\footnotetext{
${ }^{47}$ AEM Handbook (n 10) 2.

${ }^{48}$ AEM Handbook (n 10) 76.

${ }^{49}$ AEM Handbook (n 10) 19.

${ }^{50}$ AEM Handbook (n 10) 92.

51 Nicolas de Sadeleer, Environmental Principles: From Political Slogans to Legal Rules (OUP, 2002); David Freestone and Ellen Hey, The Precautionary Principle and International Law: the Challenge of Implementation (Kluwer Law International, 1996); Tim O'Riordan, James Cameron and Andrew Jordan, Reinterpreting the Precautionary Principle (Cameron and May, 2001) 3. For the European Union see, Treaty on European Union, 1992 (Maastricht Treaty), Article 130.
} 
- include appropriate zoning and development controls to limit the vulnerability of development to flooding; and

- ensure infrastructure is designed with its potential impacts on flood behaviour in mind and making it fit for purpose when needed in response to floods. ${ }^{52}$

These objectives offer some relatively specific guidance for risk managers. They suggest the seeds of a nascent, more uniform approach than we have seen in the past and easily translate into normative principles to steer decision-making. As table one below demonstrates, the outcomes identified in the AEM Handbook are increasingly being incorporated into State based planning instruments.

A close reading of the AEM Handbook suggests the authors were more experienced and more aware of the limitations of strategic, risk based, land use planning than the authors of the SCARM Report. To fill the gaps in that approach - for instance, when a comprehensive floodplain management plan is unavailable - and to provide some useful guidance on the baseline parameters for 'acceptable risk', the AEM Handbook falls back on a more conservative and more normative approach to floodplain development. In particular, and in contrast to the SCARM Report, it raises the profile of environmental considerations; acknowledges a conservative approach is warranted where information is lacking and it offers some specific principles, capable of normative application, to flesh out the minimal parameters for acceptable risk.

\section{Flood management planning instruments in New South Wales, Queensland and Victoria}

In Australia, floodplain management (and land use planning generally) lies primarily within the jurisdiction of State and Territory governments. The extent to which each State has taken up the recommendations of the SCARM Report and the AEM Handbook varies across the states. Of the three jurisdictions under review in this article, the influence of the 2000 SCARM Report can most readily be discerned in the floodplain management regime operating in New South Wales (NSW). In this jurisdiction, the pre-eminent guideline for dealing with flood prone land is the 2005 Floodplain Development Manual which incorporates the NSW Flood Prone Land Policy (the NSW Policy). ${ }^{53}$ Following in the footsteps of the SCARM Report, the NSW Policy accepts that "flood prone land is a valuable resource that should not be sterilised by unnecessarily precluding its development". ${ }^{54}$ It encourages the preparation and use of floodplain risk management plans and provides a wealth of additional guidance on how to prepare these plans. It includes detailed advice on the economic, social and environmental

\footnotetext{
${ }^{52}$ AEM Handbook (n 10) 87.

53 New South Wales Government, New South Wales Flood Prone Land Policy (New South Wales Government, 2005).

${ }^{54}$ New South Wales Government (n 53) s 1.1.
} 
issues to be considered and offers some general benchmarks for acceptable development. ${ }^{55}$ It cautions against the use of rigid or prescriptive criteria, however, because this could result in some appropriate proposals being "unreasonably disallowed or restricted". ${ }^{56}$ For this reason, the Manual falls short of setting definitive boundaries on what may constitute acceptable development. At the end of the day, it falls back on the notion that councils should "manage future flood risk to an acceptable level based on social, economic and ecological, as well as flooding considerations". ${ }^{57}$

In Queensland, the 2017 State planning policy includes a section on natural hazards, risk and resilience. The overall objective is that risks (including flooding risks) are avoided or mitigated to an acceptable or tolerable level, increasing community resilience and decreasing the burden for emergency management. ${ }^{58}$ The basic premise is that, when preparing their local planning schemes, local governments will undertake a hazard study and apply a risk assessment process to identify whether the level of risk in different areas is acceptable, tolerable or intolerable. ${ }^{59}$ Planning scheme strategies, codes and provisions should then be applied to reduce the level of risk to acceptable or tolerable levels by either avoiding or mitigating the risk. ${ }^{60}$ Before 2017, local councils were entirely free to choose between a strategy of avoiding risks altogether or mitigating those risks to an acceptable or tolerable level. ${ }^{61}$ In 2017, the relevant wording was amended to give preference to avoiding development in a flood hazard area except "where it is not possible". ${ }^{62}$ Further guidance on the precise parameters of that statement is not yet available so it is too early to say whether this new language will be influenced, for instance, by the Sequential and Exceptional tests for new development embodied in the United Kingdom's National Planning Policy Framework. ${ }^{63}$

\footnotetext{
${ }^{55}$ New South Wales Government (n 53) Appendix J and K.

${ }^{56}$ New South Wales Government (n 53) s 1.1.

${ }^{57}$ New South Wales Government ( $n$ 53) s 1.1.2.

${ }^{58}$ Queensland Government, State Planning Policy 2017 (Queensland Government, 2017) 50.

${ }^{59}$ In the 2016 State interest guideline acceptable risk is defined as a risk that is "sufficiently low to require no new treatments or actions to reduce risk further"; tolerable risk is: "A risk that, following an understanding of the likelihood and consequences, is low enough to allow the exposure to continue, and at the same time high enough to require new treatments or actions to reduce risk. Society can live with this risk but believe that as much as is reasonably practical should be done to reduce the risks further." Queensland Department of Infrastructure, Local Government and Planning (QDILGP), State Planning Policy - State interest guideline: Natural hazards, risk and resilience (Queensland Government, 2016) 5.

${ }^{60}$ Model code provisions, including sample performance criteria and specific acceptable outcomes, are provided in the State interest guideline (n 59).

${ }^{61}$ Queensland Government, State Planning Policy 2016 (Queensland Government, 2016) 35.

${ }^{62}$ Queensland Government (n 58) 51.

${ }^{63}$ The Sequential Test provides that inappropriate development in areas at risk of flooding should not be allowed if there are appropriate sites reasonably available in areas with a lower probability of flooding. If that is not possible, the Exception Test can be applied to demonstrate, "development provides wider sustainability benefits to the community that outweigh flood risk" in which case, "a site specific flood risk assessment must demonstrate that the development will be safe for its lifetime taking account of the vulnerability of its users, without increasing flood risk elsewhere, and, where possible, will reduce flood risk
} 
Of the three jurisdictions under review, the new ideas promoted in the AEM Handbook are best reflected in Victoria's state-wide statutory planning instrument, the Victorian Planning Provisions (VPP). For instance, in addition to protecting life, property and community infrastructure from flood hazard, the VPP instruct decision-makers to ensure their local planning instruments protect the natural flood carrying capacity of rivers, streams and floodways as well as the flood storage function of floodplains and waterways. ${ }^{64}$ Councils should identify urban floodway zones and overlays identifying land subject to inundation in their local planning schemes. ${ }^{65}$ These must ensure that any development: maintains the free passage and temporary storage of floodwater; minimises flood damage and is compatible with flood hazard and local drainage conditions. Overall, councils should "avoid intensifying the impacts of flooding through inappropriately located uses and developments". ${ }^{66}$ These provisions reflect the elevated status of environmental considerations in the AEM Handbook.

Table 1 summarises how, if at all, the specific objectives in the AEM Handbook, identified above, are reflected in the relevant planning instruments in New South Wales, Queensland and Victoria. Variations in the extent to which the various State planning instruments reflect the specific objectives in the AEM Handbook may relate, at least in part, to the date of the relevant State planning documents. For instance, the Queensland planning instruments, made as recently as 2017, include all but one of the specific objectives in the relevant statutory instrument (the other is covered in guidance material). This suggests there is an emerging trend, at the state level, towards identifying specific decision-making principles to complement the strategic land use planning of local floodplain entities. The basic assumption remains, however, that land use planning on floodplains is primarily the responsibility of local floodplain entities (usually local councils).

Table 1: Implementation of AEM objectives in State planning instruments

\begin{tabular}{|l|l|l|l|l|l|l|}
\hline Objective & $\begin{array}{l}\text { NSW - } \\
\text { Mandatory }\end{array}$ & $\begin{array}{l}\text { NSW - } \\
\text { Guidance } \\
\text { material }\end{array}$ & $\begin{array}{l}\text { Victoria - } \\
\text { Mandatory } \\
\text { requirement or } \\
\text { consideration }\end{array}$ & $\begin{array}{l}\text { Victoria - } \\
\text { Guidance } \\
\text { material }\end{array}$ & $\begin{array}{l}\text { QLD - } \\
\text { Mandatory } \\
\text { requirement or } \\
\text { consideration }\end{array}$ & $\begin{array}{l}\text { Qld - } \\
\text { Guidance } \\
\text { material }\end{array}$ \\
\hline
\end{tabular}

overall" National Policy Planning Framework (Department of Communities and Local Government (UK), 2012) Cl 101 and 102.

64 Department of Environment, Land, Water and Planning (DELWP), Victoria Planning Provisions (VPP) (Victoria State Government, 2016) Cl 13.02 and floodplain areas of environmental significance or of importance to river health.

${ }^{65}$ DELWP (n 64) $\mathrm{Cl} 37.03$ and 44.04.

${ }^{66}$ DELWP (n 64) Cl 37.03 and 44.03-04. In addition to the VPP, the Victoria floodplain management strategy, 2016, clarifies the roles and responsibilities of government agencies and authorities involved in flood management and uniform flood plain development guidelines are currently under development. See further, Victoria State Government, Victorian Floodplain Management Strategy (The State of Victoria Department of Environment, Land, Water and Planning: 2016) < https://www.water.vic.gov.au/managing-floodplains/newvictorian-floodplain-management-strategy> accessed 23 November 2017. 


\begin{tabular}{|c|c|c|c|c|c|c|}
\hline & $\begin{array}{l}\text { Requirement } \\
\text { or } \\
\text { consideration }\end{array}$ & & & & & \\
\hline $\begin{array}{l}\text { Limit impacts on } \\
\text { existing } \\
\text { communities }\end{array}$ & & $x$ & $x$ & & $x$ & $x$ \\
\hline $\begin{array}{l}\text { Does not } \\
\text { unduly increase } \\
\text { disaster } \\
\text { management } \\
\text { burden }\end{array}$ & & & & & $x$ & $x$ \\
\hline $\begin{array}{l}\text { Be compatible } \\
\text { with existing } \\
\text { flood functions } \\
\text { and hazard }\end{array}$ & & $x$ & $x$ & & $x$ & $x$ \\
\hline $\begin{array}{l}\text { Protect more } \\
\text { vulnerable } \\
\text { people }\end{array}$ & & & $x$ & & & $x$ \\
\hline $\begin{array}{l}\text { Use zoning and } \\
\text { development } \\
\text { controls to limit } \\
\text { flood } \\
\text { vulnerability in } \\
\text { development }\end{array}$ & & $x$ & $x$ & & $\mathrm{x}$ & $x$ \\
\hline $\begin{array}{l}\text { Ensure } \\
\text { infrastructure } \\
\text { addresses its } \\
\text { impact on flood } \\
\text { behaviour and } \\
\text { is fit for } \\
\text { purpose during } \\
\text { floods }\end{array}$ & & $x$ & $x$ & & $x$ & $x$ \\
\hline Key documents & $\begin{array}{l}\text { NSW Flood } \\
\text { Prone Land } \\
\text { Policy } 2005\end{array}$ & $\begin{array}{l}\text { Floodplain } \\
\text { Developme } \\
\text { nt Manual } \\
2005\end{array}$ & $\begin{array}{l}\text { VPP (chapters } \\
13.02 \text { and } 37.03 \\
\text { (urban floodway } \\
\text { zone) }\end{array}$ & $\begin{array}{l}\text { Victoria } \\
\text { Floodplain } \\
\text { Management } \\
\text { Strategy, 2016 }\end{array}$ & SPP 2017 & $\begin{array}{l}\text { State } \\
\text { interest } \\
\text { guideline } \\
\text { (model } \\
\text { code } \\
\text { provision) } \\
2016\end{array}$ \\
\hline
\end{tabular}

\section{Case studies from the courts}

In Australia, various courts and tribunals have the power to review the merits of local councils' planning decisions. This section describes and compares the interpretation and application of flooding policies and principles in some contested, individual development applications across NSW, Queensland and Victoria. In each case, it notes the role played by any relevant floodplain management plan or other planning instrument (including applicable state policies) and how principles such as 'affordable risk management' and 'acceptable levels of risk' were applied in practice. It also comments on whether and how the specific objectives listed in the AEM Handbook were considered whether or not that document was cited directly. Lastly, it identifies whether a practical, affordable (and invariably pro- 
development) risk management solution was favoured or whether a more conservative approach - even to the extent of refusing development - resulted.

\section{Stockland Development Pty Ltd v Sunshine Coast Regional Council and Others [2014] QPELR 52}

The Sunshine Coast lies approximately $100 \mathrm{~km}$ north of Brisbane in South East Queensland, one of Australia's most rapidly urbanising regions. With its long coastline and proximity to Brisbane, the Sunshine Coast is considered a desirable place to live. In Stockland $v$ SCRC, Stockland (the appellant) had applied for a preliminary approval to develop a master planned community comprising 950 residential allotments capable of housing approximately 2,000 people on land identified as subject to flooding. The current use of the land was for farming and current and draft planning instruments favoured the continuation of that use so the Sunshine Coast Regional Council (SCRC) (the respondent) refused the application. Stockland appealed that decision arguing that, despite conflicts with the planning scheme, there were sufficient grounds ${ }^{67}$ to justify approving the application primarily a need for new housing. Although not the only issue, the flood prone status of the land was discussed in some detail and clearly had a bearing on the judge's final decision. ${ }^{68}$

To get around the conflicts with the planning scheme, the appellant highlighted the land's location within the "Urban Footprint" of the South East Queensland Regional Plan and its former designation as an urban growth area in Council's draft growth management strategy. The appellant also made reference to the subsequent 2008 Sunshine Coast Growth Management Position Paper which identified flooding constraints as the primary reason why the land was no longer considered suitable for urban development. The appellant's argument was that, if flooding was the main constraint preventing urban development, then, provided the flooding constraint was adequately mitigated, urban development should be allowed.

The measures put forward by the appellant to mitigate the flooding risk were:

- Filling the site so that it would be immune from flood to at least the ARI 100-year event, including allowing for potential sea level rise from future climate change.

- Reconstructing the David Low Way, immediately east of the Motorway, so that it would be immune from flooding in the event of a 1 in 50 year DFE and would remain

\footnotetext{
${ }^{67}$ In Queensland the relevant legislation at the time allowed a decision contrary to a planning scheme if there are sufficient grounds - Sustainable Planning Act, 2009, s 326.

68 Stockland Development Pty Ltd v Sunshine Coast Regional Council and Others [2014] QPELR 52 [83].
} 
trafficable, albeit inundated to some extent, in a 1: 100 year flood event. ${ }^{69}$ This would achieve compliance with the requirements of the current Planning Scheme and result in a development with significantly greater flood immunity than the neighbouring Twin Waters Residential Estate. ${ }^{70}$

- An evacuation and a "shelter in place" strategy. This included filling part of the site to achieve probable maximum flood (PMF) immunity, thereby providing an area to which isolated residents could resort to seek refuge, on site, until the flood waters recede. ${ }^{71}$

The respondent conceded the appellants could use engineering solutions to mitigate the flooding hazard. It maintained, however, that, in this particular case, the risks should be avoided - by not permitting the development to go ahead - rather than mitigated - by filling the site and adopting an emergency management plan. Council claimed its position had support in the draft planning scheme which adopted an "avoid if practicable but mitigate if not" approach to development. ${ }^{72}$

On appeal, the presiding judge, his Honour Judge Rackemann, agreed with this "conservative" approach to managing the flood risk:

The development would result in the raising of the David Low Way and the creation of a flood refuge in an area prone to flooding but, on the other hand, would locate an additional residential population, of approximately 2000 people, into the floodplain, thereby potentially putting more people at risk and potentially adding to the burden on local and state emergency responses in times of disaster. ${ }^{73}$

That level of risk was unacceptable in the context of the applicable planning instruments. Overall, the appellant had failed to demonstrate a strong or overwhelming need for housing otherwise than in accordance with the planning scheme. ${ }^{74}$

The discussion in this case raised the question whether development should be avoided altogether or mitigated by way of development controls and design features (an approach consistent with cost-benefit analysis and ALARP principles). As we have seen above, in Queensland, the SPP contemplates both strategies and until 2017 councils were entirely free to choose between avoiding the risk of flooding altogether or allowing development subject to appropriate mitigation measures. In this case, Council had opted for a risk averse strategy of avoidance. Even though all the parties agreed the risk could in fact be mitigated to an

\footnotetext{
${ }^{69}$ Stockland (n 68) [88].

70 Stockland (n 68) [90].

${ }^{71}$ Stockland (n 68) [96]. For an explanation of the term 'ARI' (annual recurrence interval) see, n 17.

72 Stockland ( $\mathrm{n} 68$ ) [192] citing s 3.10.2.1c of the draft planning scheme. Council's approach preceded but closely resembles the 2017 SPP in which avoidance is identified as the preferred approach where possible.

73 Stockland (n 68) [192].

${ }^{74}$ Stockland (n 68) [209].
} 
acceptable or tolerable level, the judge affirmed Council's preference for avoiding development altogether: "That 'avoid if practicable but mitigate if not' approach is conservative, but understandable and worthy of some respect." 75 In the light of this decision, it was unnecessary to discuss in any detail what 'affordable risk management measures' might apply. Instead, Council's conservative planning instruments trumped more flexible notions of acceptable and affordable risk management. Simply put, a normative, risk averse approach prevailed over and above a 'technical fix'.

While the discussion in this case revolved around a choice between avoidance or mitigation, it is also worth noting that, although the AEM Handbook was not directly referenced in his judgment, Judge Rackemann assessed the application against three of the specific objectives identified therein: limit the burden on disaster management services; respect flood zoning and ensure infrastructure is fit for purpose (see table two below). In Judge Rackemann's view, the proposal fared poorly against all three of those objectives.

Table 2: How the AEM Handbook's specific objectives were applied in the case law

\begin{tabular}{|l|l|l|l|}
\hline Objective & Stockland & Radray & Lakeside \\
\hline $\begin{array}{l}\text { Limit impacts on existing } \\
\text { communities }\end{array}$ & Not applicable. & $\begin{array}{l}\text { XX } \\
\text { Considered - found } \\
\text { unacceptable }\end{array}$ & Not applicable. \\
\hline $\begin{array}{l}\text { Do not unduly increase disaster } \\
\text { management burden }\end{array}$ & $\begin{array}{l}\text { XX } \\
\text { Considered - found } \\
\text { unacceptable }\end{array}$ & Not argued & Not argued. \\
\hline $\begin{array}{l}\text { Be compatible with existing } \\
\text { flood functions and hazard }\end{array}$ & Not argued. & $\begin{array}{l}\text { XX } \\
\text { Considered - found } \\
\text { unacceptable }\end{array}$ & $\begin{array}{l}\text { XX } \\
\text { Considered - found } \\
\text { unacceptable. }\end{array}$ \\
\hline $\begin{array}{l}\text { Protect more vulnerable people } \\
\text { Not applicable. }\end{array}$ & $\begin{array}{l}\text { XX } \\
\text { Considered - found } \\
\text { unacceptable }\end{array}$ & $\begin{array}{l}\text { XX } \\
\text { Considered - found } \\
\text { unacceptable. }\end{array}$ \\
\hline $\begin{array}{l}\text { Use zoning and development } \\
\text { controls to limit flood } \\
\text { vulnerability in new } \\
\text { development }\end{array}$ & $\begin{array}{l}\text { XX } \\
\text { Considered - planning } \\
\text { intent to avoid } \\
\text { development was upheld. }\end{array}$ & $\begin{array}{l}\text { XX } \\
\text { Considered - zoning did } \\
\text { not adequately reflect } \\
\text { flooding hazard and } \\
\text { proposed controls were } \\
\text { insufficient for senior } \\
\text { residents. }\end{array}$ & $\begin{array}{l}\text { XX } \\
\text { Considered - zoning did not } \\
\text { adequately reflect flooding } \\
\text { hazard and proposed controls } \\
\text { were insufficient. }\end{array}$ \\
\hline $\begin{array}{l}\text { EX } \\
\text { its impact on flood behaviour } \\
\text { and is fit for purpose }\end{array}$ & $\begin{array}{l}\text { XX } \\
\text { Considered - proposed } \\
\text { improvements were not } \\
\text { sufficient to eliminate the } \\
\text { risk. }\end{array}$ & $\begin{array}{l}\text { Refused } \\
\text { evacuation routes were } \\
\text { unacceptable. }\end{array}$ & $\begin{array}{l}\text { XX } \\
\text { Considered - found } \\
\text { unacceptable. }\end{array}$ \\
\hline Outcome & Refused & Refused \\
\hline
\end{tabular}

XX - Considered and found non-compliant

$\mathrm{X}$ - Considered and found to be compliant

75 Stockland (n 68) [100]. 


\section{Radray Constructions v Hornsby Shire Council [2014] NSWLEC 1024}

In a different jurisdiction and on a different scale, Radray Constructions $v$ Hornsby Shire Council [2014] NSWLEC 1024 involved a development application in NSW for 13 dwellings earmarked for the elderly (classed a Seniors Living development). The land was zoned as low density (Res A) development in the relevant local planning scheme ${ }^{76}$ and there were no floodway restrictions in operation despite flood events as recent as 2010 and 2012. Nevertheless, Council refused the application due to its concerns about the risks of flooding. The experts' agreed flood modelling indicated the nature of that risk:

- approximately $74 \%$ of the site would be inundated in a 100 year flood event and $100 \%$ of the site would be inundated in a probable maximum flood (PMF); and

- approximately $44 \%$ of the site had velocity-depth products exceeding $0.4 \mathrm{sq}$ $\mathrm{m} / \mathrm{s}$ in a 100 year event. This value is the threshold for safe pedestrian movement.

On appeal, the developer argued that various mitigation works included in the development proposal would satisfactorily deal with the flooding issues. ${ }^{77}$ The application proposed:

- to raise floor levels in each apartment above the level of the Probable Maximum Flood (PMF) - residents would be able to remain safely in their units during significant storm events;

- to flood proof the basement car park above a 1:100 year DFE; and

- to elevate footpaths on the site above the 1:100 year DFE to ensure safe egress at all times.

In other measures, the developer proposed engineering work to improve flood storage and conveyance across the site and to make the body corporate responsible for clearing and maintaining flood routes in accordance with a comprehensive, emergency management plan. To cover all bases, there would be flood hazard signage within the development; flood information contained in the contract of sale package and on-going requirements on the site's body corporate to provide flood awareness information to residents. ${ }^{78}$

This impressive array of holistic risk management measures persuaded Commissioners Hussey and Dixon the engineering solutions were "technically sufficient" to protect the units from flooding. ${ }^{79}$ They certainly went above and beyond the safeguards generally anticipated in the NSW Floodplain Development Manual. ${ }^{80}$ Nevertheless, there remained a number of

\footnotetext{
${ }^{76}$ Radray Constructions v Hornsby Shire Council [2014] NSWLEC 1024 [80].

${ }_{77}^{7}$ Radray (n 76) [28].

${ }^{78}$ Radray (n 76) [16].

${ }^{79}$ Radray (n 76) [91].

${ }^{80}$ Above $\mathrm{n} 53$.
} 
residual issues and consequential impacts which ultimately defeated the appeal. The Commissioners considered the proposed engineering works would impact adversely on the existing streetscape and neighbourhood amenity. They were also concerned that, in a 1 in 20 year flooding event, the engineering works would increase the velocity of flood waters and the depth of flood water on adjoining properties. In less drastic but potentially more frequent flooding events, the communal gardens would be flooded and this could be particularly distressing for the elderly occupants. ${ }^{81}$ Such "intangible damages" were identified as a relevant consideration for decision-makers in the NSW Floodplain Development Manual 2005.82 Disruptions to normal routines, damage to the communal gardens and the time and cost associated with remediation work were potential stress factors which might cause "varying psychological difficulties for some residents, with severity again depending on the degree of damage or disruption, and the existing health status or vulnerability of the older person." 83 Taking all these issues into account, the appeal was dismissed and Council's refusal was confirmed.

In Radray the applicable planning instruments failed to identify the flood hazard on the site. In these circumstances, the major premise of both the SCARM Report and the AEM Handbook - that decision-making should be in accordance with a comprehensive, riskweighted, strategic floodplain management plan - was simply not an available option. In the absence of a floodplain management plan, there was no clear, evidence backed, policy guidance for the court to follow and no recognised measure of the community's risk appetite. Instead, the court had to engage in its own form of analytic-deliberative decisionmaking in order to decide whether the level of risk at stake was acceptable. Ultimately, the Commissioners found the engineering solutions proposed by the developer were "technically sufficient" but the proposed development was unacceptable nevertheless. This contrasts with the relevant discussion in the SCARM Report and NSW Flood Prone Land Policy, where decision-makers were and are urged to set the parameters of acceptable risk by reference to affordable and practical risk management measures.

In Radray, the specific objectives listed in the AEM Handbook - although not directly referenced - proved a more useful litmus test for the Commissioners than abstract concepts of affordable and acceptable risk management. When measured against five of the specific objectives in the AEM Handbook (see table 2), the proposal was found wanting.

After considering all the circumstances of the case, including the policy conflicts (the land was zoned for residential development but acknowledged by both parties to be at risk of flooding), information shortcomings and a vulnerable class of people (the elderly) as the target market, the Commissioners adopted a risk averse solution and refused the appeal. The proponent's suite of affordable, practical and technically competent solutions was not

\footnotetext{
${ }^{81}$ Radray (n 76) [133]-[135].

82 New South Wales Government (n 76) Appendix M: Flood Damages.

${ }^{83}$ Radray (n 76) [71].
} 
sufficient to render the risk acceptable in this case. Instead, as in the Stockland case, the court took the ultimate precaution of rejecting the development proposal. That approach, although not favoured by the relevant State or local planning instruments, was consistent with advice in the AEM Handbook to the effect that, where there are gaps in the knowledge base, decision-makers should exercise their powers, "in a precautionary way". ${ }^{84}$

\section{Lakeside Numurkah Developments Pty Ltd v Moira Shire Council [2013] VCAT 1355}

In this Victorian case, Moira Shire Council had refused (by not deciding) an application to sub-divide twelve vacant lots into 64 residential lots on land located $1.4 \mathrm{~km}$ north-east of Numurkah town centre. Numurkah is a town located on the banks of Broken Creek and the development site also lay close to the river. The land in dispute was zoned Residential Class 1 and various planning documents identified Numurkah (particularly north and east of the town centre) as a township ripe for "accommodating urban consolidation". 85 Two flood overlays applied across part of the site but in 2012 local flooding exceeded the current predictions for a 1 in 100 year flood event in both those instruments.

As in the previous cases, the Applicant acknowledged the risk of flooding but argued it could be appropriately managed in the design of the subdivision. Among the design measures proposed, the Applicant planned to raise the lots to ensure floor levels 0.3 metres higher than that recommended and to design the main access road to serve as a floodway for flood water when required. ${ }^{86}$ The Goulburn Broken Catchment Management Authority (GBCMA), a referral authority for the application, had not objected to the application given these and other design details. ${ }^{87}$ In the Victorian Civil and Administrative Tribunal (VCAT), however, Member Potts reaffirmed the decision of Council and refused the application. Whilst accepting there was policy support for subdivision of the land, Member Potts believed the flooding risk and associated hazards should not be overlooked:

I do not accept the Applicant's submission that the absence of flood control provisions over most of the subject site somehow conveys a message that there is a lesser degree of risk... This land is clearly subject to flooding from 1:100 ARI events. It would be folly to ignore this fact or to assign a lesser degree of risk just because the land was not subject to an RFO [Rural flood overlay] or LSIO [Land subject to inundation overlay]..$^{88}$

Particular design issues that concerned Member Potts included the developer's reliance on the wider flood plain to absorb the small decrease in on-site flood storage and the proposal's

\footnotetext{
${ }^{84}$ AEM Handbook (n 10) 92.

${ }^{85}$ Lakeside Numurkah Developments Pty Ltd v Moira Shire Council [2013] VCAT 1355 at [43]-[44].

${ }^{86}$ Lakeside (n 85) [57].

${ }^{87}$ Lakeside (n 85) [20].

${ }^{88}$ Lakeside ( $\mathrm{n} 85$ ) [34]-[35]. See $\mathrm{n} 17$ for an explanation of the ARI (Annual recurrence interval).
} 
failure to provide on-site water treatment. ${ }^{89}$ In the view of Member Potts, solutions to these issues needed to be found on site to ensure "no net loss". To allow otherwise would conflict with "a general planning policy principle" to avoid "the longer term impact of incremental affects that accumulate with each such planning decision".90 Overall Member Potts concluded the proposal "seeks more than can be accommodated by the constraints of its floodplain storage function, i.e. it is an overdevelopment of the land." 91 The appeal was refused.

As in Radray's case, the land in dispute in Lakeside was not covered by a comprehensive, risk based, floodplain management plan. On the contrary, relevant planning instruments identified the land as falling within a Residential class zone in a policy context generally supportive of more intensive urban development. Moreover, the Rural Flood and Land Subject to Inundation overlays which applied to part of the land were regarded as inaccurate on the basis of recent flood events. As in both the previous cases, the developer accepted there was a flooding hazard and offered affordable engineering solutions to manage the risk. Nevertheless, as in the two previous cases, those measures were not considered sufficient. More was at stake. In particular, the proposal was not self-sufficient - it relied on the wider floodplain to absorb some potential flooding - and, as such, could not maintain existing flood storage capacity. In giving priority to this concern, Member Potts reflects the heightened attention to environmental issues in the AEM Handbook. Furthermore, when judged against four of the specific objectives identified in the AEM Handbook (see table 2) - mirrored in this case in relevant Victorian planning instruments - the proposal was found wanting despite the design solutions offered by the developer.

\section{Analysis - why the persistence of risk aversion?}

The cases discussed in this article, although small in number, cover a spectrum of residential development applications (ranging from 950 to 13 new dwellings) across three different jurisdictions in Australia. Despite their differences, the cases exhibit two common decisionmaking themes. First, with or without reference to the AEM Handbook or relevant planning policy instruments, the courts are routinely applying the specific objectives identified in the AEM Handbook as normative criteria - or performance outcomes - against which development applications are assessed. In the 'hard cases' which typify those that end up in the courts, comprehensive, consistent, up to date and reliable strategic planning instruments - the Holy Grail of floodplain management policy - are often unavailable. In the absence of that guidance, the specific objectives identified in the AEM Handbook (and

\footnotetext{
89 Lakeside (n 85) [73].

${ }^{90}$ Lakeside (n 85) [52].

${ }^{91}$ Lakeside (n 85) [55].
} 
increasingly in high level, state policy instruments) provide a ready tool kit of decisionmaking principles and values against which to assess the risk management solutions on offer.

The second theme emanating from the cases discussed in this article is the persistence of risk averse decision-making. In individual cases, the SCARM Report and NSW Flood Prone Land Policy encourage decision-makers to establish an acceptable level of risk with reference to the availability of affordable risk management measures - a technical fix to reduce risk to as low as reasonably practicable. Surprisingly, this market driven, adaptive solution did not prevail in the cases under review. In all three of the cases discussed above, the courts accepted evidence a technical fix was possible but nevertheless went on to refuse outright the development proposed. In Australia's liberalised planning systems - where continuous growth, urban consolidation and the interests of the development industry hold great sway ${ }^{92}$ - the fact that all three cases were refused despite the ready availability of a technical fix is both surprising and noteworthy. The applicants were not only turned down by the courts. Prior to litigation, each application had been refused by the relevant local council - flouting the growth oriented reputation of Australian local councils. ${ }^{93}$

Of course, the cases discussed above are a very small sample. In an attempt to gauge whether this preference for risk aversion is more prevalent, the author surveyed reported decisions of the same courts and tribunal (The Planning and Environment Court (QId), the Land and Environment Court (NSW) and the Victorian Civil Appeal Tribunal (Victoria) for the period 2010-1018. During that period, across the three jurisdictions, there were 49 appeals involving merits review of residential development applications in which flooding issues comprised a significant factor (with $20 \%$ or more relevance to the decision). Development permits were granted in only 12 of those cases. ${ }^{94}$ In many cases in which a development permit was refused the relevant council had also refused the application but, significantly,

\footnotetext{
${ }^{92}$ Philippa England and Amy McInerney, "Anything goes? Performance based planning and the slippery slope in Queensland planning law" (2107) 34 Environmental and Planning Law Journal 238; Bob Birrell, Kevin O'Connor, Virginia Rapson and Earnest Healey, Melbourne 203: Planning rhetoric versus urban reality (Monash University ePress, 2005); Cameron Murray and Paul Fritjers, Game of Mates: How favours bleed the nation (Murray and Fritjers, 2017) chapter 2; Queensland Crime and Corruption Commission, Operation Belcarra: A blueprint for integrity and addressing corruption risk in local government (Queensland Government, 2017).

93 England and Mclnerney (n 92); Paul Stein, "The use of land at a metropolitan and local level: the retreat from planning" in Patrick Troy (Ed) Serving the City: the Crisis in Australia's Urban Services (Pluto Press, 1999); Patrick Troy, Equity, environment, efficiency: ethics and economics in urban Australia (Melbourne University Press, 2000).

${ }^{94}$ The cases which found in favour of residential development were: Arora Construction Pty Ltd \& Anor v Gold City Coast \& Anor \{2012] QPEC 052; Peake v Boroondara CC [2012] VCAT 1216; Mugavin v Moyne SC [2014] VCAT 1187; Rooke v Greater Bendigo CC [2013] VCAT 2123; Hoy v Wangaratta CC [2015] VCAT 1377; Koura Property Group Trust Pty Ltd v Whitehorse CC [2012] VCAT 1089; Dallarex Pty Ltd v Macedon Ranges SC [2013] VCAT 1995; Morris v Mornington Peninsula SC [2011] VCAT 2047; Kala Developments Pty Ltd v Surf Coast SC [2011] VCAT 513; Sketch Design Studio v Manly Council [2015] NSWLEC 1202; Season Group Pty Ltd v Council of the City of Sydney [2016] NSWLEC 1354; Dennes v Port Macquarie-Hastings Council [2016] NSWLEC 1345. This information is gathered from a search of the AUSTLII data base (viewed 10/05/2018).
} 
that was not always the case. This evidence suggests risk avoidance is an attractive option for the courts whether or not Council has also adopted that strategy. ${ }^{95}$

It appears that, in the real world of actual decision-making, risk aversion, despite its low profile in official policy documents, still has a prominent role to play. This begs the question: why are the courts and councils opting for risk avoidance over mitigation in these cases? Three possible explanations come to mind. First, there is the prospect of future liability for poorly designed or inappropriately located development. In general, local governments are only liable if their decision-making is manifestly unreasonable ${ }^{96}$ but, in an era of climate change and revolving door politics, ${ }^{97}$ legal liability for poor decision-making remains a possibility. ${ }^{98}$ Indeed, some councils have gone so far as to explicitly recognise this consideration in their planning schemes. In the Gold Coast City Plan, for instance, the Flood overlay code identifies "whether the development is likely to cause damage that would adversely affect land and /or premises to an extent likely to be actionable" as one criterion for assessing new development. ${ }^{99}$ "Better safe than out of pocket" might be the rule of thumb steering decision-makers in this respect.

Secondly, decision-makers will be well aware of the devastation that results in the immediate aftermath of flooding events. Sadly, such events are by no means rare across Australia and many existing communities have experienced a heavy financial and emotional toll as result of flooding. ${ }^{100}$ Can we really afford to risk continuing the legacy of historic planning decisions which contributed to this mess? Perhaps, in reality, our risk appetite sits somewhere below the optimism of 'affordable' or 'reasonably practical' risk management measures. If our resilience to flooding is not quite as strong as our leaders would like to think then decision-making that is "Better safe than sorry" may be preferable.

Thirdly, decision-makers face the dilemma of increasing uncertainty. Contrary to the accepted wisdom of the SCARM Report, that flooding hazard is a relatively well known and predictable risk, ${ }^{101}$ lived experience suggests our information base is incomplete and unreliable. ${ }^{102}$ This was amply demonstrated in the Radray and Lakeside cases. As fast as we

\footnotetext{
95 See, for instance, Cottam v Benalla Rural CC [2013] VCAT 1892; West Gippsland Catchment Management Authority v East Gippsland SC [2016] VCAT 1580; King \& Anor v Glen Eira CC [2013] VCAT 711.

${ }^{96}$ See, for instance, Civil Liability Act, Qld, 2003, s 35.

97 Philippa England, "Too much, too soon? On the rise and fall of Australia's coastal climate change law" (2013) 30 Environmental and Planning Law Journal 390; Philippa England, "Planning and development dilemmas in a minority government: restoring community or held to ransom?" (2016) 33(1) Environmental and Planning Law Journal 31. 98 Justine Bell, Climate Change and Coastal Development Law in Australia (Federation Press, 2014) chapter 7; Jan McDonald, "A Risky Climate for Decision-making: the Liability of Development Authorities for Climate Change Impacts" (2007) Environmental and Planning Law Journal 405; Philippa England, "Heating Up: Climate Change Law and the Evolving Responsibilities of Local Government" (2008) 13 Local Government Law Journal 209.

${ }^{99}$ Gold Coast City Plan, 2016, 8.2.8 Flood overlay code at 8.2.8.2.

${ }^{100}$ Australian Business Roundtable for Disaster Resilience and Safer Communities, n 18.

101 SCARM Report (n 9) 5.

102 Klinke and Renn (n 33) 1074.
} 
accrue reliable knowledge our information base is overtaken by events. Climate change, ecological complexity and fragmented decision-making make flooding risks less predictable and more contested than decision-makers have previously assumed. ${ }^{103}$ Information gaps and changing circumstances mean that in some (or even many) situations there will be a degree of "apparently irreducible ignorance" which may not be resolvable "at least not in the time frame within which decisions must be made". ${ }^{104}$ So what are the courts to do? How can a risk be assessed as acceptable or tolerable if we don't really know what the risk is? In these circumstances perhaps it is not so surprising decision-makers erred on the side of caution in each of the cases discussed above. There was little else to fall back on.

In her work on administrative constitutionalism, Fisher draws our attention to the "thickness of legal culture" meaning that "ideas, aspirations and mentalities shape understandings of the administrative world". ${ }^{105}$ She argues the relationship between law, public administration and technological risk is "driven forward by debates over the legitimacy of public administration." 106 Each of the reasons identified above - fear of legal liability; low risk appetites and increasing uncertainty - resonate well with this analysis. They highlight an underlying concern to arrive at legitimate (and readily defensible) - decisions in response to uncertainty. ${ }^{107}$ Ultimately, a concern with legitimate decision-making - as opposed to "writing a checklist or carrying out an algorithm" - may well be what is driving the risk averse, defensive attitude of the local councils and courts in these cases. ${ }^{108}$

\section{Risk aversion, precautionary and robust decision-making.}

This section assesses the value of risk averse decision-making, of the type exhibited in this article, in the light of two approaches to decision-making applicable in situations of scientific uncertainty. The first approach, applying the precautionary principle, has an established presence in Australian environmental law and other jurisdictions. ${ }^{109}$ The second approach, robust decision-making, features prominently in recent climate change adaptation literature. The overall argument is that, in recent years, the precautionary principle in Australia, has shifted too far in the direction of a rational-instrumental interpretation that assumes a cost effective, technical fix will readily apply despite the existence of scientific

\footnotetext{
${ }^{103}$ SREX Report (n 1) Summary for policymakers, 5-7.

104 Stephen Dovers and John Handmer, "Ignorance, sustainability and the precautionary principle: Towards an analytical framework" in Ronnie Harding and Elizabeth Fisher, Perspectives on the Precautionary Principle (Federation Press, 1999) 167 at 180.

105 Fisher (n 13) 35.

106 Fisher (n 13) 39.

107 Fisher (n 13) 39; Elizabeth Fisher and Ronnie Harding, "The precautionary principle and administrative constitutionalism: the development of frameworks for applying the precautionary principle" in Elizabeth Fisher, Judith Jones and Rene von Schomberg, Implementing the Precautionary Principle: Perspectives and Prospects (Edward Elgar, 2006) 132.

108 Elizabeth Fisher, "The precautionary principle and administrative constitutionalism" in Fisher, Jones and Schomberg (n 107) 113 at 132.

${ }^{109}$ Fisher, Jones and Schomberg (n 107); Harding and Fisher (n 104). See also n 51.
} 
uncertainty. Robust decision-making, on the other hand, changes the underlying premises. It elevates the importance of "keeping options open" in response to scientific uncertainty even at the expense of short term, optimal cost-benefits.

Australian environmental law is underpinned by the concept of ecologically sustainable development - an Australian variation on sustainable development. ${ }^{110}$ This concept embraces the precautionary principle, defined as:

[I]f there are threats of serious or irreversible environmental damage, lack of full scientific certainty should not be used as a reason for postponing measures to prevent environmental degradation; ${ }^{111}$

A significant body of Australian case law has considered and applied the precautionary principle. ${ }^{112}$ Fisher describes two strands of thought emerging from this jurisprudence. ${ }^{113}$ Commencing in the early 1990s, it was initially described as a 'common sense' principle requiring decision-makers to act cautiously in situations of scientific uncertainty. ${ }^{114}$ This interpretation had some value - it required decision-makers to identify, acknowledge and address issues of scientific uncertainty as part of the decision-making process. To the extent it urged 'caution' in response to scientific uncertainty it also presupposed a substantive outcome - but only at the vaguest level. If existing guidelines and codes already allowed for generous safety margins around risky activities, or if conditions in development approvals addressed potential environmental impacts in a reasonably comprehensive way, then decision-makers were free to argue their approach was already compliant with the principle. ${ }^{115}$ A similar tendency has been observed in the United States' treatment of the

\footnotetext{
${ }^{110}$ Commonwealth Government, National Strategy for Ecologically Sustainable Development (AGPS, 1992) available at http://www.environment.gov.au/about-us/esd/publications/national-esd-strategy; Council of Australian Governments (COAG) Intergovernmental Agreement on the Environment 1992 (AGPS, 1992) available at http://www.environment.gov.au/about-us/esd/publications/intergovernmental-agreement; Environment Protection and Biodiversity Conservation Act 1999 (Cth), s 3. See further, Gerry Bates, "Ecologically Sustainable Development: the template for environmental management" in Gerry Bates, Environmental Law in Australia (LexisNexis, 2016) chapter 8.

${ }^{111}$ Environment Protection and Biodiversity Conservation Act 1999 (Cth), s 3A.

${ }^{112}$ For a sample, see: Leatch v National Parks and Wildlife Service and Shoalhaven City Council (1993) 81 LGERA 270; Nicholls v Director-General, National Parks and Wildlife Service (1994) 84 LGERA 397; Greenpeace Australia Ltd v Redbank Power Co Pty Ltd (1994) 86 LGERA 143; Conservation Council of South Australia v Development Assessment Committee and Tuna Boat Owners Association (no.2) [1999] SAERDC 86; Telstra Corporation Ltd v Pine Rivers Shire Council [2001] QPELR 350; BGP Properties Pty Ltd v Lake Macquarie City Council [2004] NSWLEC 399; Murrimbidgee Groundwater Preservation Association v Minister for Natural Resources [2004] NSWLEC 122; Telstra Corporation Ltd v Hornsby Shire Council [2006] NSWLEC 133; Parker v Minister for Sustainability, Water, Population and Communities [2012] FCAFC 94.

113 Fisher (n 13) chapter 4. See also, Bates (n 110) 300.

114 Leatch v National Parks and Wildlife Service and Shoalhaven City Council (n 128) 81 at 282; Greenpeace Australia Ltd v Redbank Power Co Pty Ltd (n 113) 143 at 154; Conservation Council of South Australia v Development Assessment Committee and Tuna Boat Owners Association (no.2) (n 113); Telstra Corporation Ltd v Pine Rivers Shire Council (n 112); CSR Ltd v Caboolture Shire Council [2001] QPELR 398. See further, Fisher (n 13) 140; Bates (n 110) 300.

${ }^{115}$ Fisher (n 13) 145; Bates (n 110) 315.
} 
precautionary principle. ${ }^{116}$ The European Union, on the other hand, has distinguished this sort of 'prudential approach' to scientific risk evaluation as a separate type of safeguard that operates independently of the precautionary principle. ${ }^{117}$

The second line of reasoning incorporates a more technical, rational-instrumental interpretation of the principle. In this approach, the precautionary principle, when triggered, requires decision-makers to assume the threat of serious or irreversible environmental damage is a reality (no longer just a possibility) and shifts on to the development proponent the evidentiary burden of showing a risk of harm is (or will be rendered) non-existent or negligible. ${ }^{118}$ In a landmark case, Telstra Corporation Ltd $v$ Hornsby Shire Council, Chief Justice Preston, of the NSW Land and Environment Court, endorsed this interpretation and attempted to reconcile it with the risk management literature. ${ }^{119}$ He cautioned against applying the precautionary principle too restrictively to prevent or prohibit development until full scientific certainty is achieved: "A zero risk precautionary standard is inappropriate ... [because] it would result in a paralysing bias in favour of the status quo". ${ }^{120}$ To shift away from this "paralysing bias in favour of the status quo", Chief Justice Preston argued the precautionary principle must embrace the concept of proportionality: "measures should not go beyond what is appropriate and necessary in order to achieve the objectives in question". ${ }^{121}$ Echoing the tone of the SCARM Report, he argued:

[A] reasonable balance must be struck between the stringency of the precautionary measures, which may have associated financial, livelihood and opportunity costs, and the seriousness and irreversibility of the threat. ${ }^{122}$

Chief Justice Preston also argued in favour of adaptive management techniques. For instance, a small scale, pilot project could be approved subject to conditions requiring monitoring, evaluation and adjustment if necessary. Further expansion of the project could be permitted if and when experience accrues and the degree of uncertainty declines. ${ }^{123} \mathrm{His}$ Honour's reliance on notions of proportionality and adaptive management sit comfortably with the cost conscious, rationalising, adapt-and-mitigate philosophy of mainstream

\footnotetext{
116 Joel Tickner with Carolyn Raffensperger, "The American view on the precautionary principle" in O' Riordan, Cameron and Jordan (n 51) 202.

117 European Commission (n 36) s 5.

118 Fisher (n 13) 146; Bates ( 110 ) 312; Telstra (n 112); Tim O’Riordan, James Cameron and Andrew Jordan,

“The evolution of the precautionary principle" in O' Riordan, Cameron and Jordan (n 51) 20.

119 Telstra (n 112).

120 Telstra (n 112) [179]-[181].

121 Telstra (n 112) [166] referencing, Rosie Cooney and Barney Dickson (eds), Biodiversity and the Precautionary Principle, Risk and Uncertainty in Conservation and Sustainable Use, (Earthscan, 2005). See also, Adrian Deville and Ronnie Harding, Applying the Precautionary Principle (Federation Press, 1997); de Sadeleer (n 51) chapter 3.

122 SCARM Report (n 9) [166]-[178].

${ }^{123}$ Telstra (n 112) [161]-[165].
} 
floodplain development policy. Subsequent case law has affirmed the decision in Telstra ${ }^{124}$ although some decisions still apply the more flexible interpretation. ${ }^{125}$

Justice Preston's resort to cost-benefit analysis and risk based assessment techniques to amplify the precautionary principle brings the Australian jurisprudence more into line with policy guidance from overseas. ${ }^{126}$ It is not, however, without controversy. ${ }^{127}$ A few years earlier, when the European Union issued its policy guidance on the meaning of precaution in the European Union, environmentalists took umbrage at the assertion the precautionary principle "belongs within rather than outside the framework of risk analysis, and in particular risk management". ${ }^{128}$ Their argument was that, in making this connection, the Statement undermined the central purpose of the principle - which is to deal with situations of uncertainty that cannot be adequately and reliably comprehended by scientific methods. In other words, if the precautionary principle becomes too closely aligned with methods of risk analysis and cost-benefit accounting it will lose its value as a decision-making tool that answers the questions science cannot.

Returning specifically to our discussion of flooding risks, the outcomes in the case law reviewed in this article are even more surprising in the light of the Telstra decision. In all three cases, a zero risk strategy was adopted despite the array of adaptive solutions being offered by development proponents. Contrary to the dicta in Telstra - and similar dicta in official policy documents - a risk averse decision prevailed. In other words, risk avoidance was preferred over and above risk mitigation. A quick survey of other flooding cases confirmed the preference for risk avoidance, at least to the extent development approval was refused in a large majority of those cases. Interestingly, none of the judges in the cases discussed above referred expressly to the precautionary principle. Indeed, in the light of the Telstra case, their decisions would have been more difficult to justify had they done so. Perhaps these cases provide some confirmation that reliance on cost-benefit and risk assessment tools has stalled any further, useful development of the precautionary principle.

\footnotetext{
${ }^{124}$ Environment East Gippsland Inc v VicForests [2010] VSc 335; Hamilton v Sutherland Shire Council [2012] NSWLEC 1015; Dual Gas Pty Ltd v Environment Protection Authority [2012] VCAT 308; King v Minister for Planning; Parkesbourne-Mummel Landscape Guardians Inc v Minister for Planning; Gullen Range Wind Farm Pty Ltd v Minister for Planning [2011] NSWLEC 1102.

${ }^{125}$ De Lacey v Kagara Pty Ltd [2009] QLC 77; Bates (n 110) 306.

126 United Kingdom Government, Fact not fantasy: Best Evidence (United Kingdom Government, 1990) 11; European Commission (n 36).

${ }^{127}$ For critiques of the reasoning in Telstra see, Christine Trenorden, "Judicial review and the principles of ecologically sustainable development: where are we going?" (2014) Australian Environmental Law Digest 7; Jacqueline Peel, "When (Scientific) Rationality Rules: (Mis) Application of the Precautionary Principle in Australian Mobile Phone Tower Cases", (2007) 19 Journal of Environmental Law 103; Philippa England, "Risk managing in the courts: seeds of a divergent jurisprudence" (2018) 35 Environmental and Planning Law Journal 267.

${ }^{128}$ European Commission (n 36) s 5; Andrew Jordan, "The precautionary principle in the European Union" in O'Riordan, Cameron and Jordan (n 51) 157.
} 
If the precautionary principle is in demise, an alternative approach to addressing the issue of future uncertainty is provided by the literature on robust decision-making. Robust decision-making features prominently in recent climate change adaption literature as a rational and appropriate approach to decision-making in conditions of uncertainty. ${ }^{129} \mathrm{~A}$ robust decision or plan "performs well over a wide range of plausible futures" even if it does not perform optimally in any particular scenario. ${ }^{130}$ In other words, robust decision-making allows decision-makers to move away from a rigid adherence to cost-benefit analysis and to adopt 'sub-optimal' decision-making if, in so doing, their decision-making serves to keep future options open and /or to reduce potential adverse impacts if or when future circumstances do not eventuate as predicted. In this way, robust decision-making deals well with both expected and surprising changes (i.e. uncertain ones). ${ }^{131}$ According to the logic of robust decision-making, risk averse decision-making makes good sense in the context of floodplain development decisions whenever: there is significant uncertainty; cause-effect relationships are poorly understood and /or values are unclear. ${ }^{132}$ If these circumstances apply, a decision-maker who refuses a development application is following a robust decision-making path by "keeping their options open".

Keeping options open is an important but often overlooked consideration in development assessment. A development refusal is often categorised as a 'sterilisation of the land', ${ }^{133} \mathrm{a}$ source of economic inefficiency ${ }^{134}$ and an infringement of the rights of private individuals to develop their own land. ${ }^{135}$ In reality, this is seldom the case. If a development application is refused outright there is nothing to stop a proponent putting forward another more suitable proposal in the future. It is not really a 'sterilisation' of the land. If, on the other hand, a

\footnotetext{
${ }^{129}$ SREX (n 1) 48; IPCC, "Summary for policymakers" in IPCC, Climate Change 2014: Impacts, Adaptation, and Vulnerability. Part A: Global and Sectoral Aspects. Contribution of Working Group II to the Fifth Assessment Report of the Intergovernmental Panel on Climate Change (CUP 2104) 1-32.

130 SREX (n 1) 48; IPCC (n 128) 209. On robust decision-making, see, Jonathan Rosenhead, "Robustness analysis: Keeping your options open" in Jonathan Rosenhead and John Mingers (eds), Rational Analysis for a Problematic World Revisited: Problem structuring methods for complexity (Wiley, 2001); Robert Lempert and Micheal Schlesinger, "Climate change strategy needs to be robust"(2001) 412 Nature 375; Robert Lempert and Myles Collins, "Managing the risk of uncertain threshold responses: comparison of robust, optimum and precautionary approaches" (2007) Risk Analysis 1009; Suraje Dessai and Mike Hulme, "Assessing the robustness of adaptation decisions to climate change uncertainties: A case study on water resources management in the East of England" (2007) 17 Global Environmental Change 59; Suraje Dessai, Mike Hulme and Roger Pielke Jr., "Climate prediction: a limit to adaptation?" in Neil Adger, Adapting to climate change: thresholds, values, governance (CUP, 2009) 64; Robert Lempert and David Groves, "Identifying and evaluating robust adaptation policy responses to climate change for water agencies in the American west" (2010) 77 Technological Forecasting and Social Change 960.

131 SREX (n 1) 56.

${ }^{132}$ Robert Lempert and Myles Collins, "Managing the risk of uncertain threshold responses: comparison of robust, optimum and precautionary approaches" (2007) Risk Analysis 1009, 1010.

${ }^{133}$ New South Wales Government (n 53) s 1.1.

${ }^{134}$ Andrew Maclntosh, "Coastal climate hazards and urban planning: how planning responses can lead to maladaptation" (2013) 18 Mitigation and Adaptation Strategies for Global Change 1035; Morris (n 33). ${ }^{135}$ Aldous v Greater Taree City Council [2009] NSWLEC 252; Wallace v Brisbane City Council [2011] QPEC 47; Philippa England, "The legal basis for Australian environmental planning and governance" in Jason Byrne, Neil Sipe and Jago Dodson (eds), Australian Environmental Planning (Routledge 2014) 40.
} 
development application is approved the land is locked into (relatively) irreversible change. In the adaptation literature, irreversible (or path dependent) decisions are generally not favoured if they will limit the scope for future adaptation. ${ }^{136}$ The literature on robust decision-making reminds us of the value of keeping the options open instead of viewing development decisions as a one off, point in time decision that needs to be made today. ${ }^{137}$ Applying the robust decision-making approach, the recourse to risk avoidance in the decisions of the courts and councils evident in this article is a good illustration of rational, legitimate and robust decision-making.

\section{Conclusion}

In 2001, Jaeger et al stated:

We are still faced with the original dilemma, i.e., that society has to make choices about what risks to accept and what risks to reject, but lacks the means to make a collectively binding decision that is convincing to all people affected by the decision. ${ }^{138}$

In 2000, the SCARM Report argued strategic risk management, based on multi-dimensional, floodplain management plans, combined with individual decision-making based on acceptable and affordable risk management measures was the optimal solution to this dilemma. Lived experience has proven otherwise. The 2013 AEM Handbook acknowledges there are ongoing gaps in our knowledge base. Where this is the case, it advises decisionmakers to exercise their powers, "in a precautionary way using the best available information in a conservative manner." ${ }^{139}$ It also identifies some specific objectives which readily translate into applicable normative principles without regard to questions of affordability.

In all the cases discussed in this article, the courts assessed the applications in a comprehensive and conservative manner applying some or all of the specific objectives identified in the AEM Handbook whether or not they referred to that document. In each case, the proposed development fell short when judged comprehensively and cautiously with reference to the available evidence and those specific objectives. As a result, despite the presence of affordable risk management measures - a technical fix suggested by the development proponent - all three cases were refused outright. Surprisingly, despite the

\footnotetext{
136 IPCC (n 128) 209; SREX (n 1) 54; John Barnett and Saffron O’Neill, “Maladaptation” (2009) 20 Global Environmental Change 211. See also the discussion of "quasi option choices" in David James, "Economic concepts and the precautionary principle and implementation of safe minimum standards' in Harding and Fisher (n 104) 154 at 157.

137 Rosenhead (n 129) 187; SREX (n 1) 47, 56; IPCC (n 128) 9, 28.

138 Jaeger (n 33) 115.

${ }^{139}$ AEM Handbook (n 10) 92.
} 
ascendancy of liberal, pro-growth planning regimes, risk averse decision-making prevailed over risk mitigation. Perhaps experience has taught our decision-makers to treat the rationalising, cost conscious language of strategic risk management with just a little more scepticism than in the recent past.

Word count (all inclusive): 13,340 